\title{
Enantioselective Synthesis of Benzimidazolyl Quinoxalinones on Soluble Polymer Support Using Focused Microwave Irradiation
}

\author{
Kaushik Chanda, Jaren Kuo, Chih-Hau Chen, and Chung-Ming Sun* \\ Department of Applied Chemistry, National Chiao Tung University, Hsinchu, Taiwan 300-10, ROC
}

Received August 17, 2008

\begin{abstract}
Focused microwave irradiation has been applied to a multistep synthetic sequence of reactions designed to generate benzimidazolyl quinoxalinones using a soluble polymer support. They were obtained by the ipsofluoro $\left(\mathrm{S}_{\mathrm{N}} \mathrm{Ar}\right)$ displacement of the immobilized ortho-nitro fluoro benzimidazoles with chiral alpha amino esters under microwave irradiation. Intermediate chiral organic-polymer conjugates when subjected to neutral reduction underwent a spontaneous intramolecular ring closure. Cleavage of the polymer support, at room temperature, did not cause any significant racemization resulting in the generation of a chiral molecular library with two points of structural diversity.
\end{abstract}

\section{Introduction}

A combinatorial approach for the introduction of structural diversity in small molecules has given rise to compound libraries needed for lead generation in the acceleration of drug discovery. The small molecule approach has been useful for both therapeutic and chemical target validation. ${ }^{1}$ Combinatorial libraries based on heterocyclic motif have become a popular objective in library design, because a large number of drugs may contain one or more heterocyclic rings. The potential of solid phase synthesis to produce collection of structurally diverse small molecules was first realized in the Merrifield synthesis of peptides. ${ }^{2}$ The insolubility of the linker-monomer conjugates and its lack of amenability for monitoring the progress of the reaction demanded an alternative method retaining the concept of support. Polyethylene glycols which are linear poly ethers are a class of macromolecules to which organic monomers can be covalently linked by an ester bond, the resulting polymer conjugates are found to be soluble in several organic solvents, and the reaction progress can be directly monitored by NMR. ${ }^{3-5}$ The robustness of this macromolecular carrier has been demonstrated in the synthesis of a variety of biologically active nitrogen heterocycles, which are recognized for their multidimensional importance. ${ }^{6-8}$ Despite the numerous advances in high throughput synthesis methods, a more practical approach in fast library preparation is emerging. Development of microwave-assisted library synthesis provides the rapid access to the targeted compounds, as the exploring of novel compounds with desired bioproperties is time-consuming and expensive. Time requirements, reaction temperatures, solvents, additives and catalysts, or the mole ratio of the substrate can be evaluated in microwave-assisted organic synthesis (MAOS) in a few minutes to optimize the desired chemistry. Since the advent of MAOS along with combinatorial synthesis, innumerable libraries of biologically activated molecules have been synthesized using both solid

\footnotetext{
*E-mail: cmsun@mail.nctu.edu.tw.
}

phase as well as solution phase strategies. ${ }^{9}$ A subset of these has been developed using a biologically validated heterocyclic structure as a starting point for the library design. ${ }^{10}$ We have shown the application of microwave irradiation in multistep liquid phase synthesis to generate molecular libraries of nitrogen containing heterocycles. ${ }^{11}$

Benzimidazoles $^{12}$ and quinoxalines ${ }^{13}$ are privileged nitrogen heterocycles known for a wide range of biological activities, which have been found in clinically accepted drugs as well. Quinoxalinones have been reported as diazepine receptor antagonists ${ }^{14}$ (Figure 1, A) and antithrombotic agents. ${ }^{15}$ Their potential to act as inhibitors of blood coagulation factor $\mathrm{Xa}^{16}$ and glycogen phosphorylase ${ }^{17}$ have also been realized recently. In view of their wide range of biological activities, quinoxalinones have been synthetic targets for the solid phase, ${ }^{18}$ liquid phase, ${ }^{19}$ and microwave assisted Ugi coupling methods. ${ }^{20}$

Preparation of biheterocycles with desirable pharmacological properties is an interesting aspect of heterocyclic chemistry. The two ring systems in the present context via benzimidazole and quinoxaline can give rise to a number of regioisomers of biheterocyclic benzimidazolyl quinoxalines which may potentially create new entities with unusual bioproperties through a synergistic effect. The generation of a hybridized biheterocyclic skeleton resembling druglike molecules has a substantial intellectual appeal. Receptor binding studies on human adenosine has revealed the antagonist property of the 2-2 isomers at the nanomolar level (Figure 1, B). ${ }^{21,22}$ During the study of bi- and terbenzimidazoles, it was found that 6-2 linkage of the quinoxaline and the corresponding 2,3-dione moiety greatly enhanced the DNA topoisomerase I activity (Figure 1, C). ${ }^{23}$

Stereoselectivity has been emphasized as a vital component in drug design. ${ }^{24}$ In view of this, it was thought pertinent to design a chiral library by the direct linkage of benzimidazole and quinoxaline rings to increase the molecular complexicity. We first report here the results in generating a molecular library of chiral benzimidazolyl quinoxalinones on a soluble 


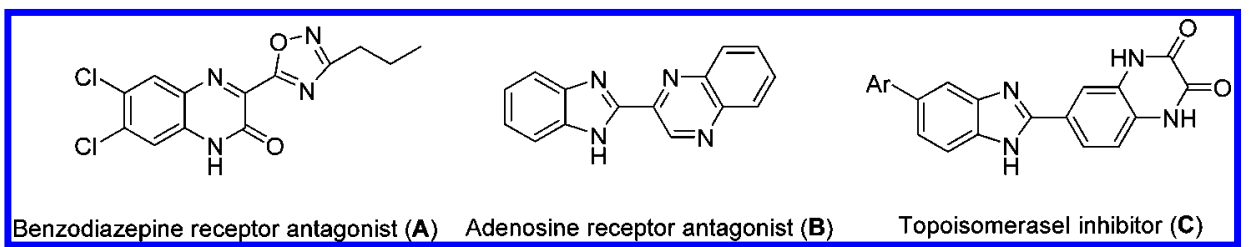

Figure 1. Structurally related biologically active compounds.

Scheme 1. Microwave Assisted Synthesis of Benzoimidazolylquinoxalinones

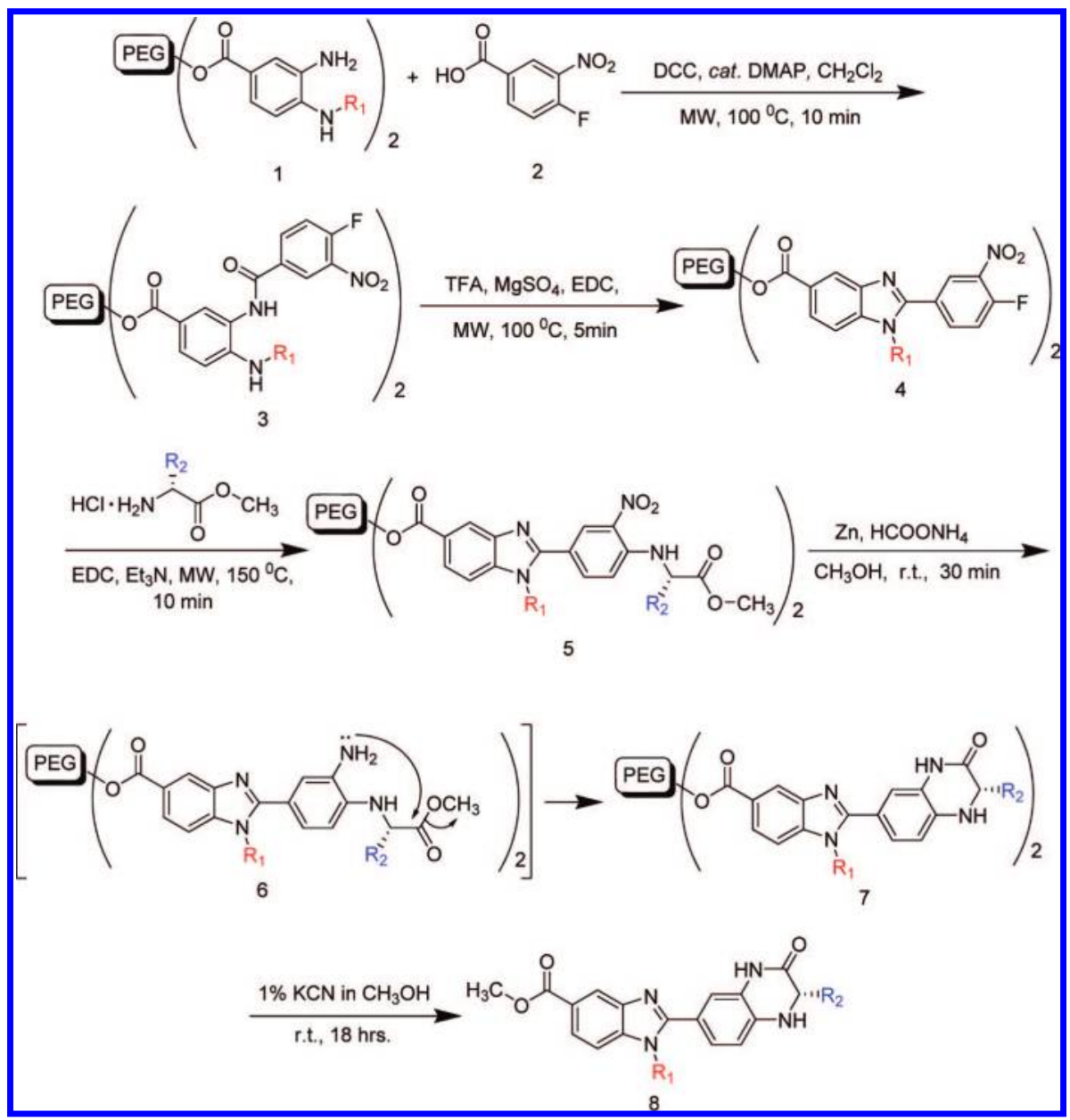

polymer support and effects of microwave (MW) irradiation to the targeted compounds on various synthetic steps.

\section{Results and Discussion}

Ortho-diamino ester conjugates 1 (Scheme 1) which are the initiators for the present strategy with a built-in structural diversity have been prepared from a three step protocol established by our group earlier. ${ }^{25}$ In order to introduce the second diversity, compound $\mathbf{1}$ was continuously reacted with 4-fluoro-3-nitro-benzoic acid 2. Anilide conjugates $\mathbf{3}$ were obtained by the condensation of acid 2 with the PEG conjugates 1 via the in situ generated DCC activated ester in refluxing dichloromethane. The required refluxing time of $24 \mathrm{~h}$ for this step was reduced to 40 min using domestic MW irradiation under open-vessel conditions. When microwave irradiation under sealed vessel conditions at $\left(100{ }^{\circ} \mathrm{C}\right.$, 8 bar; the temperature was measured by infrared ray) was applied, it took only $10 \mathrm{~min}$. The obtained anilide conjugates $\mathbf{3}$ were converted into benzimidazoles $\mathbf{4}$ by an intramolecular ring closure through the nucleophilic attack of the secondary amine on to the amide carbonyl which was induced by a mild acid (10\% TFA). Addition of anhydrous magnesium sulfate in this transformation brought down the reaction time, by facilitating the removal of water during this step, which needed $15 \mathrm{~h}$ under refluxing conditions in dichloroethane. The time for the formation of benzimidazole was reduced to 15 min by domestic MW cavity. However, the reaction time was reduced to $5 \mathrm{~min}$ in sealed vessel MW conditions $\left(100{ }^{\circ} \mathrm{C}, 5\right.$ bar). Magnesium sulfate was filtered off and the polymer conjugate 4 was purified by precipitating out the reaction mixtures with excess of cold ether.

Polymer bound benzimidazoles $\mathbf{4}$ were found to contaminate no previous intermediates and were used as such for the further steps in the present sequence. In further steps, the reactivity of ortho-nitro fluoro groups in $\mathbf{4}$ was used in a cascaded manner. Introduction of the amino functional group and the chirality in the quinoxaline moiety was achieved by the use of optically active alpha-amino esters. 
Table 1. Comparison of Microwave and Conventional Heating for the Coupling Step, Cyclization and $S_{N} A r$ Reactions

\begin{tabular}{cccccc}
\hline & & \multicolumn{3}{c}{ optimized reaction conditions } \\
\cline { 3 - 6 } entry & substrates & products & $\operatorname{time}^{a}(\mathrm{~h})$ & time $^{b}(\mathrm{~min})$ & time $^{c}(\mathrm{~min})$ \\
\hline 1 & 1 & 3 & 24 & 40 & 10 \\
2 & 3 & 4 & 15 & 20 & 5 \\
3 & 5 & 6 & 20 & 40 & 10 \\
\hline \multicolumn{2}{c}{$a$} & &
\end{tabular}

${ }^{a}$ Reflux condition. ${ }^{b}$ Domestic microwave oven (open vessel condition, $150 \mathrm{~W}) .{ }^{c}$ Biotage initiator.

The ipso-fluoro displacement with various chiral amino esters on the conjugates 4 was complete in $20 \mathrm{~h}$ in refluxing dichloroethane. The domestic MW irradiation brought down the reaction time to $40 \mathrm{~min}$. We also have found that application of focused MW reactor at $\left(150{ }^{\circ} \mathrm{C}, 7\right.$ bar) drove the reaction to completion in $10 \mathrm{~min}$ (Table 1). The resulting ortho-nitro aniline conjugates 5 were yellow in color and were purified by precipitation with cold ether, washing the solid with excess ether for purification, and vaccuum-dried prior to the next step.

One step that did not warrant the application of MW was the neutral reduction of nitro group, which was effected by using zinc dust and ammonium formate in methanol at room temperature in $30 \mathrm{~min}$ resulting in the amine conjugate $\mathbf{6}$. Neutral conditions of the reduction in methanol did not result in the protonation of the amines. It was followed by nucleophilic attack of the in situ generated amines on the ester carbonyl leading to the formation of quinoxalinone conjugates 7 . The aminolysis of nonactivated ester usually occurs under harsh conditions. In some cases, through the assistance of microwave irradiation or directly refluxing reaction mixtures in solvent-free conditions, aminolysis of nonactivated esters are much easily to proceed. ${ }^{26}$ Spontaneous in situ cyclization from conjugates 6 to 7 involving the facile aminolysis of methyl esters at ambient temperature is successful to generate lactam ring of quinoxalinone. ${ }^{27}$ The presently observed on-support cyclization is in accordance with previously reports on the synthesis of biologically active compound on solid phase support. ${ }^{28}$ Finally cleavage of the soluble polymer support was achieved using $1 \% \mathrm{KCN}$ in methanol at room temperature to obtain polymer free benzimidazolyl quinoxalinones $\mathbf{8} \mathbf{a}-\mathbf{m}$ in good to excellent yields. No uncyclized compounds were detected by mass and proton NMR. Each crude product is subsequently analyzed by HPLC and ranges in purity from 70 to $94 \%$. (Table 2) By employing the desired reaction sequence, we are able to introduce two diverse substitutions that have a large number of building blocks readily available.

Normally, monitoring the progress of organic reaction on solid phase support by regular proton NMR is very difficult because of the insolubility of conjugated material in the solvent, but it is possible for the compounds attached with polyethylene glycol which itself act as soluble polymer support. The amenability of the present synthetic sequence to NMR monitoring reaction progress has been demonstrated in Figure 2. Formation of the anilides $\mathbf{3 i}$ from conjugates $\mathbf{1 i}$ is supported by the appearance of the low field $\mathrm{NH}$ proton around $9.3 \mathrm{ppm}$, which is also characterized by the presence of signals at 8.8 and $8.4 \mathrm{ppm}$ (Spectrum B) due to the aromatic protons in the ortho-nitro fluoro moiety. Benzimi- dazole conjugates $4 \mathbf{i}$ indicates the absence of the low field $\mathrm{NH}$ proton at $9.3 \mathrm{ppm}$, whereas the aromatic protons (spectrum $\mathrm{C}$ ) were shifted downfield due to the amide $\mathrm{NH}$ and secondary amine being converted into a more electron withdrawing benzimidazole derivative. Reaction with amino acid esters results in the substitution of the electron withdrawing fluorine, which is indicated by the appearance of an upfield signal at $6.8 \mathrm{ppm}$ (spectrum D) of the proton attached to carbon atom near to the fluorine atom. Cyclization to the quinoxalinone conjugates $\mathbf{7}$ was only observed after detachment of the product from polymeric support which showed the absence of the low field triplet around $4.4 \mathrm{ppm}$ due to PEG. Observed signal characteristics of different protons are in agreement with structures 8i (Figure 2, spectrum E).

Maintenance of chiral integrity of the conjugates $\mathbf{5}$ and 7 during reductive cyclization could not be monitored due to the presence of the macromolecular support. Chiral HPLC analysis of $\mathbf{8 b}$ obtained after the final cleavage showed about $10 \%$ racemization $(80 \%$ enantiomeric excess (ee)) (Figure 3).

High enantiomeric excesses of final cleaved compounds were observed in the majority of the cases, showing practically a very insignificant loss of chirality, during the three step reaction on the polymer support in MW harsh conditions (Table 2).

To this end, no side products arising from the oxidation of the 3,4 carbon/nitrogen bond were found when polymerfree compounds 8 were released, as predicted from an acidfree, concurrent self-cyclization step (5 to 6). Ito et al. ${ }^{29}$ have reported that acid treatment of quinoxalinones causes oxidation of the 3,4 carbon/nitrogen bond. We did observe the the compounds $\mathbf{8}$ slowly lost their chirality to the compound 9 when they were stirred in acidic chloroform solution for several days at room temperature (Scheme 2). ${ }^{30}$

\section{Conclusions}

In summary, we have successfully demonstrated the application of soluble polymer support combined with MW technology, as a highly useful method for the generation of chiral benzimidazolylquinoxaline-2-one library. A comparison with solution phase chemistry shows that synthesis of the quinoxalinone ${ }^{31}$ and benzimidazole ${ }^{32}$ ring requires the use of ortho-diamines or ortho-dinitro benzaldehydes which are to be again synthesized from $o$-nitro compounds under harsh conditions of acid or alkali. Further, Retaining the ester functions by routine synthesis on the aryl ring becomes a formidable task. Hence, the use of PEG-support seems to be most vital to retain the ester function which can be further elaborated on the heterocyclic scaffold. The synthetic route mainly emphasizes the MW reaction conditions and simple workup procedures resulting in druglike products with higher optical purities. Compared with conventional thermal heating, microwave irradiation decreased the reaction time on the support from several hours to a few minutes. It is also worth noting that the PEG-monomer conjugates and polymer support itself remain stable under pressured microwave irradiation. The coupling of microwave tech- 
Table 2. Microwave Assisted Liquid Phase Synthesis of Optically Active Benzimidazolylquinoxalinone Libraries 8a-m

\begin{tabular}{|c|c|c|c|c|c|c|}
\hline Entry & $R_{1}$ & $\mathbf{R}_{2}$ & $\mathrm{~m} / \mathrm{z}$ & Yield $^{a}$ & Purity $^{b}$ & $e^{\circ}$ \\
\hline $8 a$ & & & 468 & 88 & 73 & 98 \\
\hline $8 b$ & & & 392 & 94 & 86 & 80 \\
\hline $8 c$ & & & 507 & 84 & 91 & 92 \\
\hline $8 d$ & & & 514 & 91 & 75 & 88 \\
\hline $8 e$ & & & 480 & 89 & 86 & 87 \\
\hline $8 f$ & & & 434 & 94 & 94 & 95 \\
\hline $8 \mathrm{~g}$ & & & 469 & 92 & 81 & 96 \\
\hline $8 \mathrm{~h}$ & & & 507 & 86 & 91 & 82 \\
\hline $8 i$ & & & 434 & 95 & 70 & 97 \\
\hline $8 \mathrm{j}$ & & & 392 & 84 & 86 & 99 \\
\hline $8 k$ & & & 420 & 89 & 76 & 95 \\
\hline 81 & & & 404 & 87 & 76 & 98 \\
\hline $8 m$ & & & 432 & 93 & 81 & 80 \\
\hline
\end{tabular}

${ }^{a}$ Determined based on the weight of crude samples (\%). ${ }^{b}$ Determined by HPLC analysis (UV detection at $254 \mathrm{~nm}$ of the crude product $(\%)$. ${ }^{c}$ Determined by HPLC on chiral DIACEL CHIRACEL OD using $n$-hexane/2-propanol as solvents.

nology with liquid-phase combinatorial synthesis constitutes a novel and attractive platform for the rapid generation of novel biologically active compounds with high enantioselectivity.

\section{Experimental Section}

General Procedure for the Preparation of Polymer Bound 3-(4-Fluoro-3-nitrobenzamido)-4-(Substituted Amino) Carboxylates 3. Polymer bound $o$-phenylene diamine 1 (PEG 4000) (1.0 g, $0.25 \mathrm{mmol}, 1.0$ equiv) dissolved in (5 $\mathrm{mL}$ ) of dichloromethane was added to a solution of 4-fluoro3-nitrobenzoic acid (0.11 g, $0.60 \mathrm{mmol}, 2.4$ equiv) in dichloromethane $(5 \mathrm{~mL})$ in the presence of $N, N^{\prime}$-dicyclohexylcarbodiimide (DCC) $(0.144 \mathrm{~g}, 0.70 \mathrm{mmol}, 2.4$ equiv) and $N, N^{\prime}$ - dimethylamino pyridine (DMAP) $(3 \mathrm{mg})$. The reaction mixture was stirred at room temperature and subsequently irradiated microwave for $10 \mathrm{~min}$ to obtain the polymer bound amide conjugates $\mathbf{3}$. After completion of the reaction, the suspensible dicyclohexyl urea (DCU) was filtered through filter paper. The reaction mixtures were precipitated by slow addition of cold ether and precipitated amide conjugate $\mathbf{3}$ was filtered through fritted funnel. The crude product was washed successively with ether to remove the undesired impurity and dried for further steps.

General Procedure for the Preparation of Polymer Bound Benzimidazole Derivatives 4. To a solution of $\mathbf{3}$ in 1,2-dichloroethane, trifluoroacetic acid $(0.5 \mathrm{~mL})$ and $\mathrm{MgSO}_{4}$ $(0.5 \mathrm{~g})$ were added and irradiated under microwave conditions for $5 \mathrm{~min}$. After completion of the reaction, $\mathrm{MgSO}_{4}$ was removed through celite. The reaction mixtures were precipitated by slow addition of excess of cold ether (100 $\mathrm{mL}$ ) and filtered through a fritted funnel to obtain the compound $\mathbf{4}$ in high purity.

General Procedure for the Preparation of Polymer Bound Substituted Benzimidazole Derivatives 5. The polymer bound benzimidazole derivative $\mathbf{4}$ was treated with 


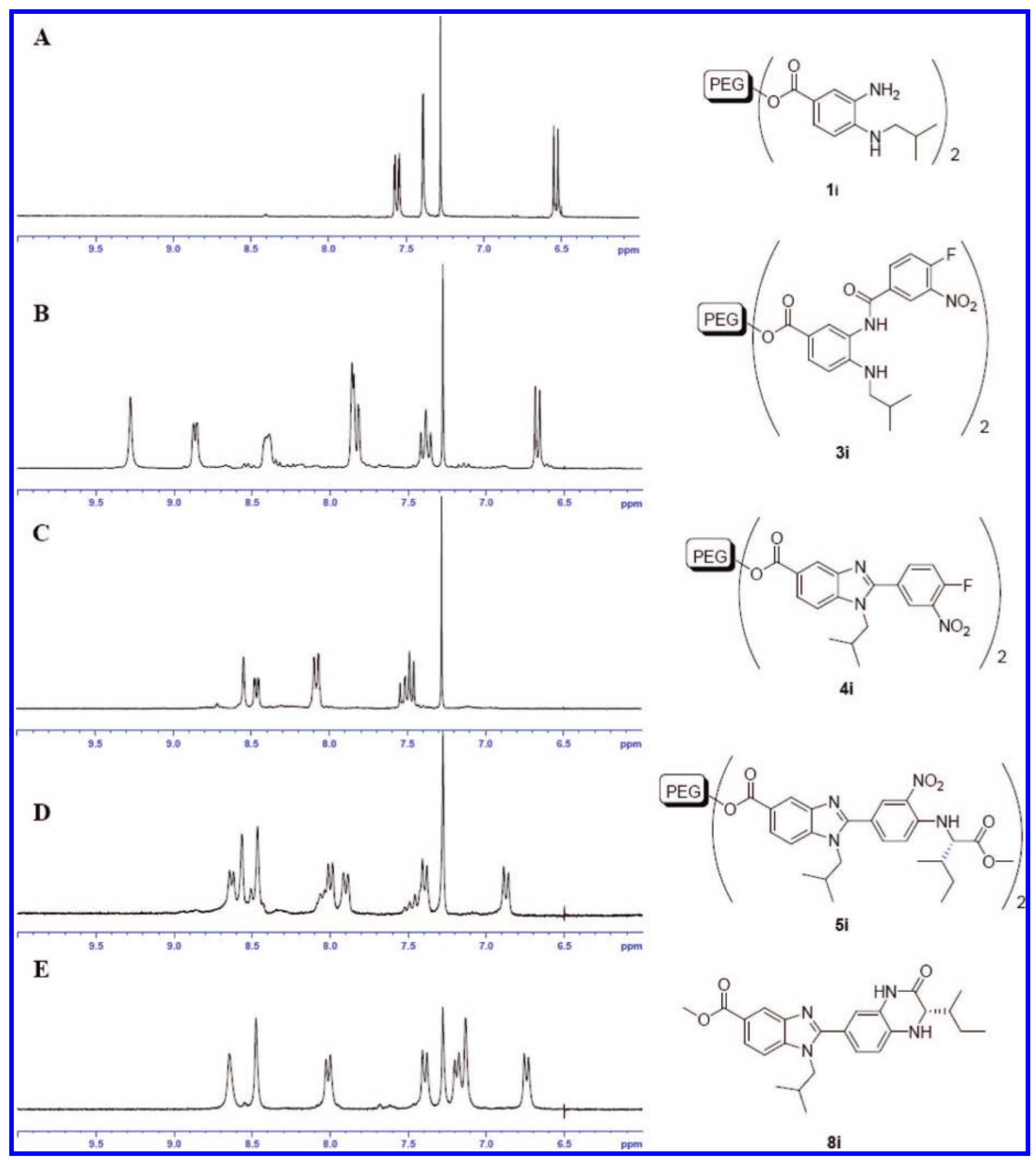

Figure 2. ${ }^{1} \mathrm{H}$ NMR monitoring reactions of benzimidazolyl quinoxalinone.

various chiral amino esters ( 5 equiv) and $\mathrm{Et}_{3} \mathrm{~N}$ ( 3 equiv) in 1,2-dichloroethane $(5 \mathrm{~mL})$. The reaction mixtures were irradiated under microwave condition for $10 \mathrm{~min}$ to complete $\mathrm{S}_{\mathrm{N}} \mathrm{Ar}$ reaction and the reaction mixtures were washed with cold ether $(100 \mathrm{~mL})$, dried to obtain the conjugate $\mathbf{5}$ in quantitative yields.

General Procedure for the Preparation of Polymer Bound Substituted Benzimidazolylquinoxalinone Derivatives 7. To a solution of 5 in methanol, $\mathrm{Zn}(0.5 \mathrm{~g}, 7.5 \mathrm{mmol}$, 30 equiv) and ammonium formate $(0.24 \mathrm{~g}, 3.75 \mathrm{mmol}, 15.0$ equiv) were added. The crude mixtures were stirred for 30 min for complete reduction of nitro group which was evident from color change from yellow to colorless. The reaction mixtures were then subjected to centrifugation for removal of $\mathrm{Zn}$ and the supernatant liquid was concentrated by rotary evaporation to remove methanol. Dichloromethane (10 $\mathrm{mL})$ was then added to salt out ammonium formate. The reaction mixtures were filtered through filter paper to remove ammonium formate to obtain the conjugate 7 .

General Procedure for the Cleavage of Polymer Bound Substituted Benzimidazolylquinoxalinone Derivatives 8. To a solution of conjugates 7 in methanol $(30 \mathrm{~mL}), \mathrm{KCN}(0.1$ g) was added and stirred for $18 \mathrm{~h}$. After completion of the reaction, monitored by TLC, the crude mixture was precipitated with excess of cold ether $(100 \mathrm{~mL})$ and the polymer was filtered off and subjected to rotavapor. The residue was dried under vacuum and subjected to crude HPLC analysis with UV detection at $\lambda=254 \mathrm{~nm}$ (column Sphereclone $5 \mu$ Si $(250 \times$ $4.6 \mathrm{~mm}$ ); gradient $50 \%$ ethyl acetate in hexane; flow rate $1 \mathrm{~mL} /$ min.). The residual solid was then purified by neutral silica gel 


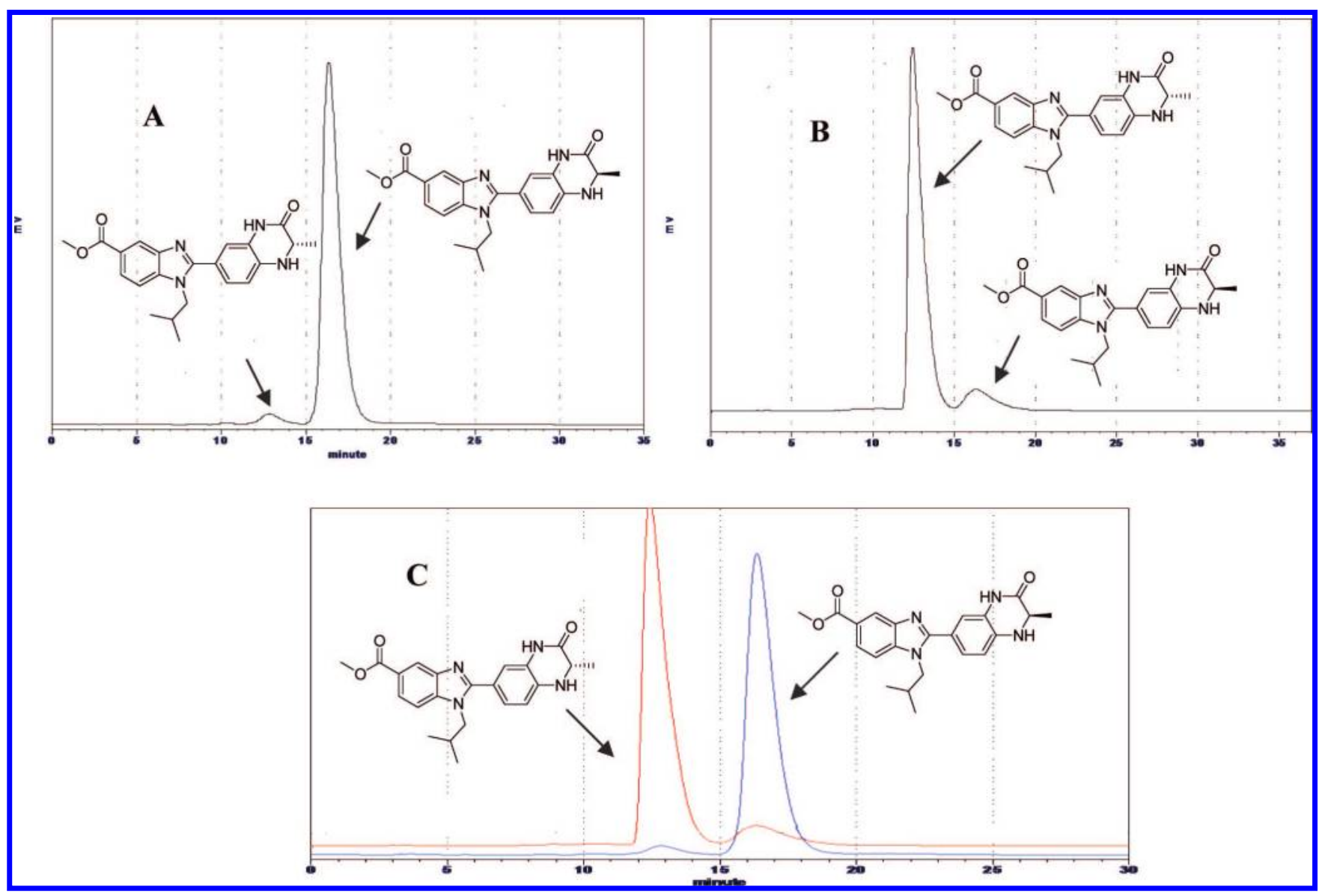

Figure 3. Chiral HPLC (diacel chiralcel OD) analysis of $\mathbf{8 b}$.

Scheme 2. Oxidation of Compounds 8 to 9 after Cleavage

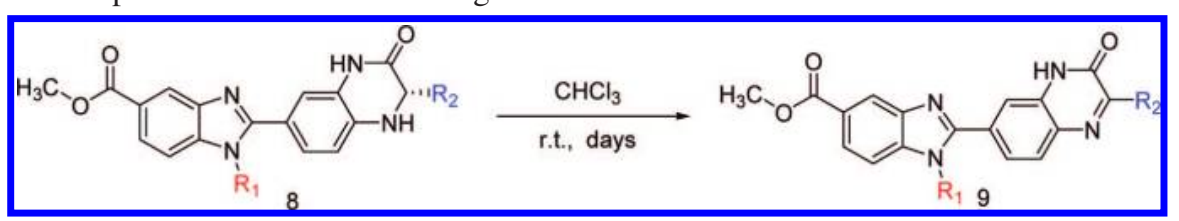

column chromatography and eluted with a mixture of ethyl acetate and hexane (2:1) to obtain the title compounds $\mathbf{8}$ in good yield and subjected to chiral HPLC analysis using chiral column (daicel chiralcel OD) employing 2-propanol: $n$-hexane (1:9) as the eluent ratio.

2-(2-Benzyl-3-oxo-1,2,3,4-tetrahydro-quinoxalin-6-yl)1-isobutyl-1H-benzoimidazole-5-carboxylic Acid Methyl Ester (8a). ${ }^{1} \mathrm{H}$ NMR $\left(300 \mathrm{MHz}, \mathrm{CDCl}_{3}\right) \delta 8.74(\mathrm{~s}, 1 \mathrm{H}), 8.47$ $(\mathrm{d}, J=1.2 \mathrm{~Hz}, 1 \mathrm{H}), 8.01(\mathrm{dd}, J=8.4,1.5 \mathrm{~Hz}, 1 \mathrm{H})$, $7.47-7.20(\mathrm{~m}, 8 \mathrm{H}), 6.68(\mathrm{~d}, J=7.8 \mathrm{~Hz}, 1 \mathrm{H}), 4.17-4.11$ (m, 4H), $3.95(\mathrm{~s}, 3 \mathrm{H}), 3.32(\mathrm{dd}, J=13.5,2.7 \mathrm{~Hz}, 1 \mathrm{H}), 2.87$ (dd, $J=13.5,11.1 \mathrm{~Hz}, 1 \mathrm{H}), 2.11(\mathrm{~m}, 1 \mathrm{H}), 0.79$ (d, $J=6.6$ $\mathrm{Hz}, 3 \mathrm{H}), 0.77(\mathrm{~d}, J=6.6 \mathrm{~Hz}, 3 \mathrm{H}) ;{ }^{13} \mathrm{C} \mathrm{NMR}(75 \mathrm{MHz}$, $\left.\mathrm{CDCl}_{3}\right) \delta 167.7,167.5,155.3,138.9,136.5,134.4,129.7$, 129.4, 129.0, 128.5, 127.6, 125.7, 125.0, 124.7, 124.3, 121.6, 116.5, 114.2, 110.3, 57.5, 52.8, 52.3, 52.1 38.2, 29.7, 28.9, 20.1, 20.0; MS (EI) $\mathrm{m} / \mathrm{z} 468$ (M+); HRMS (EI, m/z) calcd for $\mathrm{C}_{28} \mathrm{H}_{28} \mathrm{~N}_{4} \mathrm{O}_{3} \mathrm{~m} / \mathrm{z}, 468.2161$, found 468.2169; $[\alpha]_{\mathrm{D}}{ }^{20}-81.0$ (c $0.6, \mathrm{CH}_{2} \mathrm{Cl}_{2}$ ); IR ( $\mathrm{cm}^{-1}$, neat): 1748, 1660 .

1-Isobutyl-2-(2-methyl-3-oxo-1,2,3,4-tetrahydro-quinoxalin-6-yl)-1 $\boldsymbol{H}$-benzoimidazole-5-carboxylic Acid Methyl Ester (8b). ${ }^{1} \mathrm{H}$ NMR (300 MHz, $\left.\mathrm{CDCl}_{3}\right) \delta 9.02(\mathrm{~s}, 1 \mathrm{H}), 8.46$ (s, 1H), $8.01(\mathrm{dd}, J=8.2,1.5 \mathrm{~Hz}, 1 \mathrm{H}), 7.42(\mathrm{~d}, J=8.4 \mathrm{~Hz}$,
1H), $7.24(\mathrm{~s}, 1 \mathrm{H}), 7.20(\mathrm{dd}, J=8.2,1.5 \mathrm{~Hz}, 1 \mathrm{H}), 6.76(\mathrm{~d}$, $J=8.1 \mathrm{~Hz}, 1 \mathrm{H}), 4.62(\mathrm{~s}, 1 \mathrm{H}), 4.16-4.07(\mathrm{~m}, 3 \mathrm{H}), 3.95(\mathrm{~s}$, $3 \mathrm{H}), 2.08(\mathrm{~m}, 1 \mathrm{H}), 1.48(\mathrm{~d}, J=6.6 \mathrm{~Hz}, 3 \mathrm{H}), 0.76(\mathrm{~d}, J=$ $6.6 \mathrm{~Hz}, 6 \mathrm{H}) ;{ }^{13} \mathrm{C}$ NMR $\left(75 \mathrm{MHz}, \mathrm{CDCl}_{3}\right) \delta 169.0,167.7$, 155.7, 142.3, 139.2, 135.2, 125.9, 124.8, 124.4, 124.0, 121.8, 120.7, 116.4, 113.7, 110.1, 52.2, 52.1, 51.8, 28.8, 20.1, 20.0, 18.3; MS (EI) $\mathrm{m} / z: 392(\mathrm{M}+$ ); HRMS (EI, $\mathrm{m} / z$ ) calcd for $\mathrm{C}_{22} \mathrm{H}_{24} \mathrm{~N}_{4} \mathrm{O}_{3} \mathrm{~m} / \mathrm{z} 392.1848$, found 392.1847; $[\alpha]_{\mathrm{D}}{ }^{20}-83.2$ ( $c$ 1.0, $\mathrm{CH}_{2} \mathrm{Cl}_{2}$ ); IR ( $\mathrm{cm}^{-1}$, neat): 1725, 1642.

2-[2-(1H-Indol-2-ylmethyl)-3-oxo-1,2,3,4-tetrahydroquinoxalin-6-yl]-1-isobutyl-1 $H$-benzoimidazole-5-carboxylic Acid Methyl Ester (8c). ${ }^{1} \mathrm{H}$ NMR $\left(300 \mathrm{MHz}, \mathrm{CDCl}_{3}\right) \delta$ $8.82(\mathrm{~s}, 1 \mathrm{H}), 8.66(\mathrm{~s}, 1 \mathrm{H}), 8.49(\mathrm{~s}, 1 \mathrm{H}), 8.01(\mathrm{dd}, J=8.7$, $1.5 \mathrm{~Hz}, 1 \mathrm{H}), 7.59(\mathrm{~d}, J=7.5 \mathrm{~Hz}, 1 \mathrm{H}), 7.40-7.37(\mathrm{~m}, 2 \mathrm{H})$, $7.21-7.07(\mathrm{~m}, 5 \mathrm{H}), 6.58(\mathrm{~d}, J=11.1 \mathrm{~Hz}, 1 \mathrm{H}), 4.26-4.07$ (m, 4H), 3.95 (s, 3H), 3.48 (dd, $J=14.4,3.3 \mathrm{~Hz}, 1 \mathrm{H}), 3.07$ (dd, $J=14.4,11.1 \mathrm{~Hz}, 1 \mathrm{H}), 2.10(\mathrm{~m}, 1 \mathrm{H}), 0.77$ (d, $J=6.6$ $\mathrm{Hz}, 3 \mathrm{H}), 0.75(\mathrm{~d}, J=6.6 \mathrm{~Hz}, 3 \mathrm{H}) ;{ }^{13} \mathrm{C}$ NMR $(75 \mathrm{MHz}$, $\left.\mathrm{CDCl}_{3}\right) \delta 168.5,167.7,158.2,142.0,139.1,136.5,134.6$, 127.2, 126.7, 125.6, 124.8, 124.5, 124.1, 123.7, 122.2, 121.6, 120.2, 119.6, 118.6, 116.4, 114.1, 111.5, 110.3, 110.0, 56.5, 52.2, 28.9, 28.5, 28.3, 20.1; MS (EI) m/z: 507 (M+); HRMS 
(EI, $\mathrm{m} / \mathrm{z}$ ) calcd for $\mathrm{C}_{30} \mathrm{H}_{29} \mathrm{~N}_{5} \mathrm{O}_{3} \mathrm{~m} / \mathrm{z}$ 507.2270, found 507.2268; $[\alpha]_{\mathrm{D}}{ }^{20}-78.2\left(c 0.7, \mathrm{CH}_{2} \mathrm{Cl}_{2}\right)$; IR ( $\mathrm{cm}^{-1}$, neat): $1718,1682$.

2-(2-Benzylsulfanylmethyl-3-oxo-1,2,3,4-tetrahydroquinoxalin-6-yl)-1-isobutyl-1H-benzoimidazole-5-carboxylic Acid Methyl Ester (8d). ${ }^{1} \mathrm{H}$ NMR $\left(300 \mathrm{MHz}, \mathrm{CDCl}_{3}\right) \delta$ $8.92(\mathrm{~s}, 1 \mathrm{H}), 8.46(\mathrm{~s}, 1 \mathrm{H}), 8.00(\mathrm{~d}, J=8.7 \mathrm{~Hz}, 1 \mathrm{H}), 7.38(\mathrm{~d}$, $J=8.4 \mathrm{~Hz}, 1 \mathrm{H}), 7.33-7.17(\mathrm{~m}, 8 \mathrm{H}), 6.75(\mathrm{~d}, J=8.7 \mathrm{~Hz}$, $1 \mathrm{H}), 4.83(\mathrm{~s}, 1 \mathrm{H}), 4.10(\mathrm{~d}, J=7.5 \mathrm{~Hz}, 2 \mathrm{H}), 3.96(\mathrm{~s}, 1 \mathrm{H})$, $3.94(\mathrm{~s}, 3 \mathrm{H}), 3.76(\mathrm{~s}, 1 \mathrm{H}), 3.14(\mathrm{dd}, J=14.1,3.0 \mathrm{~Hz}, 1 \mathrm{H})$, $2.72(\mathrm{dd}, J=14.1,7.5 \mathrm{~Hz}, 1 \mathrm{H}), 2.21(\mathrm{~m}, 1 \mathrm{H}), 0.76(\mathrm{~d}, J=$ $6.6 \mathrm{~Hz}, 6 \mathrm{H}) ;{ }^{13} \mathrm{C}$ NMR $\left(75 \mathrm{MHz}, \mathrm{CDCl}_{3}\right) \delta 167.6,166.7$, $157.4,139.0,137.8,134.3,133.8,132.6,129.3,128.9,128.8$, $127.5,125.5,124.8,124.7,124.2,121.9,121.7,116.1,114.1$, 110.2, 54.5, 52.2, 52.1, 36.5, 34.4, 29.7, 28.9, 20.1; MS (EI) $\mathrm{m} / \mathrm{z}: 514(\mathrm{M}+)$; HRMS (EI, $\mathrm{m} / \mathrm{z}$ ) calcd for $\mathrm{C}_{29} \mathrm{H}_{30} \mathrm{~N}_{4} \mathrm{O}_{3} \mathrm{~S} \mathrm{~m} / \mathrm{z}$ 514.2039, found 514.2041; $[\alpha]_{\mathrm{D}}{ }^{20}-75.3\left(c 0.45, \mathrm{CH}_{2} \mathrm{Cl}_{2}\right)$; IR $\left(\mathrm{cm}^{-1}\right.$, neat): 1719,1680 .

2-(2-Benzyl-3-oxo-1,2,3,4-tetrahydro-quinoxalin-6-yl)1-cyclopentyl-1H-benzoimidazole-5-carboxylic Acid Methyl Ester (8e). ${ }^{1} \mathrm{H}$ NMR $\left(300 \mathrm{MHz}, \mathrm{CDCl}_{3}\right) \delta 10.00(\mathrm{~s}$, $\mathrm{NH}), 8.46(\mathrm{~s}, 1 \mathrm{H}), 7.94(\mathrm{~d}, J=8.7 \mathrm{~Hz}, 1 \mathrm{H}), 7.47(\mathrm{~d}, J=$ $8.7 \mathrm{~Hz}, 1 \mathrm{H}), 7.35-7.12(\mathrm{~m}, 7 \mathrm{H}), 6.64(\mathrm{~d}, J=8.1 \mathrm{~Hz}$, $1 \mathrm{H}), 4.98(\mathrm{~m}, 1 \mathrm{H}), 4.22-4.08(\mathrm{~m}, 2 \mathrm{H}), 3.93(\mathrm{~s}, 3 \mathrm{H}), 3.28$ $(\mathrm{dd}, J=12.9,3.0 \mathrm{~Hz}, 1 \mathrm{H}), 2.87(\mathrm{dd}, J=12.9,10.8 \mathrm{~Hz}$, $1 \mathrm{H}), 2.30-2.16(\mathrm{~m}, 2 \mathrm{H}), 2.13-1.93(\mathrm{~m}, 4 \mathrm{H}), 1.78-1.65$ $(\mathrm{m}, 2 \mathrm{H}) ;{ }^{13} \mathrm{C}$ NMR $\left(75 \mathrm{MHz}, \mathrm{CDCl}_{3}\right) \delta 168.1,167.7$, $156.0,143.1,136.6,136.5,134.3,132.8,130.1,129.5$, $129.0,128.1,127.1,125.8,125.0,124.2,123.6,122.1$, 120.7, 116.8, 114.1, 111.4, 57.7, 57.6, 52.1, 38.3, 30.6, 30.4, 25.3; MS (EI) $m / z: 480(\mathrm{M}+)$; HRMS (EI, $m / z)$ calcd for $\mathrm{C}_{29} \mathrm{H}_{28} \mathrm{~N}_{4} \mathrm{O}_{3} \mathrm{~m} / \mathrm{z}$ 480.2161, found 480.2119; $[\alpha]_{\mathrm{D}}{ }^{20}$ -83.7 (c 1.0, $\mathrm{CH}_{2} \mathrm{Cl}_{2}$ ); IR (cm ${ }^{-1}$, neat): 1717, 1675 .

1-Butyl-2-(2-s-butyl-3-oxo-1,2,3,4-tetrahydro-quinoxalin-6-yl)-1 $H$-benzoimidazole-5-carboxylic Acid Methyl Ester (8f). ${ }^{1} \mathrm{H}$ NMR $\left(300 \mathrm{MHz}, \mathrm{CDCl}_{3}\right) \delta 9.22(\mathrm{~s}, 1 \mathrm{H}), 8.45$ $(\mathrm{s}, 1 \mathrm{H}), 8.00(\mathrm{dd}, J=8.7,1.5 \mathrm{~Hz}, 1 \mathrm{H}), 7.36(\mathrm{~d}, J=8.4 \mathrm{~Hz}$, $1 \mathrm{H}), 7.17-7.14(\mathrm{~m}, 2 \mathrm{H}), 6.71(\mathrm{~d}, J=5.7 \mathrm{~Hz}, 1 \mathrm{H}), 4.41(\mathrm{~s}$, $1 \mathrm{H}), 4.20$ (t, $J=7.5 \mathrm{~Hz}, 2 \mathrm{H}), 3.93(\mathrm{~s}, 3 \mathrm{H}), 2.27-2.16(\mathrm{~m}$, $3 \mathrm{H}), 1.79(\mathrm{~m}, 3 \mathrm{H}), 1.54(\mathrm{~d}, J=6.8 \mathrm{~Hz}, 2 \mathrm{H}), 1.02(\mathrm{~d}, J=$ $6.8 \mathrm{~Hz}, 3 \mathrm{H}), 0.91-0.80(\mathrm{~m}, 6 \mathrm{H}) ;{ }^{13} \mathrm{C}$ NMR $(75 \mathrm{MHz}$, $\left.\mathrm{CDCl}_{3}\right) \delta 167.7,167.5,155.4,138.9,135.2,125.4,124.7$, 124.5, 124.0, 121.7, 118.9, 116.2, 112.9, 109.9, 109.7, 61.1, 52.1, 44.8, 38.6, 31.9, 24.5, 19.9, 15.3, 13.2, 12.1; MS (EI) $m / z: 434$ (M+); HRMS (EI, $\mathrm{m} / \mathrm{z}$ ) calcd for $\mathrm{C}_{25} \mathrm{H}_{30} \mathrm{~N}_{4} \mathrm{O}_{3} \mathrm{~m} / \mathrm{z}$ 434.2318, found 434.2317; $[\alpha]_{\mathrm{D}}{ }^{20}-75.8\left(c 0.9, \mathrm{CH}_{2} \mathrm{Cl}_{2}\right)$; IR $\left(\mathrm{cm}^{-1}\right.$, neat): $1733,1657$.

2-(2-Benzyl-3-oxo-1,2,3,4-tetrahydro-quinoxalin-6-yl)1-butyl-1H-benzoimidazole-5-carboxylic Acid Methyl Ester $(\mathbf{8 g}) .{ }^{1} \mathrm{H}$ NMR $\left(300 \mathrm{MHz}, \mathrm{CDCl}_{3}\right) \delta 9.48(\mathrm{~s}, 1 \mathrm{H}), 8.46$ (s, $1 \mathrm{H}), 8.01(\mathrm{~d}, J=8.4 \mathrm{~Hz}, 1 \mathrm{H}), 7.39-7.12(\mathrm{~m}, 8 \mathrm{H}), 6.67$ $(\mathrm{d}, J=8.4 \mathrm{~Hz}, 1 \mathrm{H}), 4.28-4.13(\mathrm{~m}, 4 \mathrm{H}), 3.94(\mathrm{~s}, 3 \mathrm{H}), 3.30$ (dd, $J=13.5,2.4 \mathrm{~Hz}, 1 \mathrm{H}), 2.87(\mathrm{dd}, J=13.5,10.2 \mathrm{~Hz}$, $1 \mathrm{H}), 1.75(\mathrm{~m}, 2 \mathrm{H}), 1.31(\mathrm{~m}, 2 \mathrm{H}), 0.89(\mathrm{t}, J=7.2 \mathrm{~Hz}, 3 \mathrm{H})$; ${ }^{13} \mathrm{C}$ NMR $\left(75 \mathrm{MHz}, \mathrm{CDCl}_{3}\right) \delta 168.0,167.7,155.3,142.4$, $138.9,136.5,134.3,129.5,129.3,129.0,128.6,127.2,125.8$, 124.8, 124.5, 124.1, 121.8, 120.6, 116.6, 114.2, 109.8, 57.6, 52.1, 44.8, 38.2, 31.8, 20.0, 13.6; MS (EI) $m / z: 468$ (M+); HRMS (EI, $m / z$ ) calcd for $\mathrm{C}_{28} \mathrm{H}_{28} \mathrm{~N}_{4} \mathrm{O}_{3} \mathrm{~m} / z$ 468.2161, found
468.2159; $[\alpha]_{\mathrm{D}}^{20}-77.3$ (c 1.1, $\mathrm{CH}_{2} \mathrm{Cl}_{2}$ ); IR ( $\mathrm{cm}^{-1}$, neat): $1718,1678$.

1-Butyl-2-[2-(1H-indol-2-ylmethyl)-3-oxo-1,2,3,4-tetrahydro-quinoxalin-6-yl]-1 $H$-benzoimidazole-5-carboxylic Acid Methyl Ester (8h). ${ }^{1} \mathrm{H}$ NMR $\left(300 \mathrm{MHz}, \mathrm{CDCl}_{3}\right) \delta$ 8.85 (s, 1H), 8.60 (s, 1H), 8.49 (s, 1H), 8.02 (d, $J=7.5$ $\mathrm{Hz}, 1 \mathrm{H}), 7.61(\mathrm{~d}, J=7.5 \mathrm{~Hz}, 1 \mathrm{H}), 7.38(\mathrm{t}, J=8.1 \mathrm{~Hz}$, $2 \mathrm{H}), 7.23-7.08(\mathrm{~m}, 5 \mathrm{H}), 6.60(\mathrm{~d}, J=8.1 \mathrm{~Hz}, 1 \mathrm{H})$, $4.30-4.19(\mathrm{~m}, 4 \mathrm{H}), 3.95(\mathrm{~s}, 3 \mathrm{H}), 3.47(\mathrm{dd}, J=14.1,3.0$ $\mathrm{Hz}, 1 \mathrm{H}), 3.08(\mathrm{dd}, J=14.1,10.5 \mathrm{~Hz}, 1 \mathrm{H}), 1.81(\mathrm{~m}, 2 \mathrm{H})$, $1.28(\mathrm{~m}, 2 \mathrm{H}), 0.89(\mathrm{t}, J=7.2 \mathrm{~Hz}, 3 \mathrm{H}) ;{ }^{13} \mathrm{C}$ NMR $(75$ $\left.\mathrm{MHz}, \mathrm{CDCl}_{3}\right) \delta 168.6,168.1,155.7,142.4,139.2,136.8$, $135.1,127.6,125.9,125.0,124.9,124.6,123.9,122.8$, $122.5,120.1,119.1,118.7,116.8,114.4,111.9,110.6$, 110.5, 110.2, 57.0, 52.6, 45.3, 32.2, 28.8, 13.9; MS (EI) $m / z: 507\left(\mathrm{M}+\right.$ ); HRMS (EI, $\mathrm{m} / \mathrm{z}$ ) calcd for $\mathrm{C}_{30} \mathrm{H}_{29} \mathrm{~N}_{5} \mathrm{O}_{3}$ $\mathrm{m} / \mathrm{z}$ 507.2270, found 507.2272; $[\alpha]_{\mathrm{D}}{ }^{20}-79.8$ (c 0.8 , $\mathrm{CH}_{2} \mathrm{Cl}_{2}$ ); IR ( $\mathrm{cm}^{-1}$, neat): 1720, 1683 .

1-Isobutyl-2-(2-s-butyl-3-oxo-1,2,3,4-tetrahydro-quinoxalin-6-yl)-1H-benzoimidazole-5-carboxylic Acid Methyl Ester (8i). ${ }^{1} \mathrm{H}$ NMR $\left(300 \mathrm{MHz}, \mathrm{CDCl}_{3}\right) \delta 8.46(\mathrm{~s}, 1 \mathrm{H})$, $8.42(\mathrm{~s}, 1 \mathrm{H}), 8.04(\mathrm{dd}, J=8.6,1.6 \mathrm{~Hz}, 1 \mathrm{H}), 7.40(\mathrm{~d}, J=$ $8.4 \mathrm{~Hz}, 1 \mathrm{H}), 7.19-7.13(\mathrm{~m}, 2 \mathrm{H}), 6.75(\mathrm{~d}, J=8.1 \mathrm{~Hz}, 1 \mathrm{H})$, $4.30(\mathrm{~s}, 1 \mathrm{H}), 4.15-4.10(\mathrm{~m}, 2 \mathrm{H}), 3.93(\mathrm{~s}, 3 \mathrm{H}), 2.13(\mathrm{~m}, 1 \mathrm{H})$, $1.64-1.55(\mathrm{~m}, 2 \mathrm{H}), 1.05(\mathrm{~d}, J=6.9 \mathrm{~Hz}, 2 \mathrm{H}), 0.80(\mathrm{~m}, 6 \mathrm{H})$, $0.79(\mathrm{~d}, J=6.6 \mathrm{~Hz}, 6 \mathrm{H}) ;{ }^{13} \mathrm{C}$ NMR $\left(75 \mathrm{MHz}, \mathrm{CDCl}_{3}\right) \delta$ 167.7, 167.5, 155.4, 138.9, 135.2, 125.4, 124.7, 124.5, 124.0, 121.7, 118.9, 116.2, 112.9, 109.9, 109.7, 61.1, 52.1, 44.8, 38.6, 31.9, 24.5, 19.9, 15.3, 13.2, 12.1; MS (EI) $\mathrm{m} / \mathrm{z}: 434$ $\left(\mathrm{M}+\right.$ ); HRMS (EI, $m / z$ ) calcd for $\mathrm{C}_{25} \mathrm{H}_{30} \mathrm{~N}_{4} \mathrm{O}_{3} \mathrm{~m} / z$, 434.2318, found 434.2331; $[\alpha]_{\mathrm{D}}{ }^{20}-45.0\left(c 0.1, \mathrm{CH}_{2} \mathrm{Cl}_{2}\right)$; IR $\left(\mathrm{cm}^{-1}\right.$, neat): $1715,1661$.

1-Butyl-2-(2-methyl-3-oxo-1,2,3,4-tetrahydro-quinoxalin-6-yl)-1 $\boldsymbol{H}$-benzoimidazole-5-carboxylic Acid Methyl Ester (8j). ${ }^{1} \mathrm{H}$ NMR $\left(300 \mathrm{MHz}, \mathrm{CDCl}_{3}\right) \delta 8.48(\mathrm{~s}, 1 \mathrm{H}), 8.21$ (s, $1 \mathrm{H}), 8.04$ (dd, $J=8.5,1.4 \mathrm{~Hz}, 1 \mathrm{H}), 7.42(\mathrm{~d}, J=8.5 \mathrm{~Hz}$, 1H), 7.24-7.20 (m, 2H), $6.81(\mathrm{~d}, J=7.9 \mathrm{~Hz}, 1 \mathrm{H}), 4.23(\mathrm{t}$, $J=7.9 \mathrm{~Hz}, 2 \mathrm{H}), 4.11-4.15(\mathrm{~m}, 2 \mathrm{H}), 3.36(\mathrm{~s}, 3 \mathrm{H}), 1.78-1.88$ (m, 2H), $1.53(\mathrm{~d}, J=6.6 \mathrm{~Hz}, 3 \mathrm{H}), 1.37-1.28(\mathrm{~m}, 2 \mathrm{H}), 0.92$ $(\mathrm{t}, J=7.5 \mathrm{~Hz}, 3 \mathrm{H}) ;{ }^{13} \mathrm{C}$ NMR $\left(75 \mathrm{MHz}, \mathrm{CDCl}_{3}\right) \delta 168.8$, $168.1,155.5,142.9,139.3,135.5,126.2,124.9,124.5,122.3$, $116.8,114.2,110.0,96.5,52.5,52.3,45.2,32.3,21.2,20.4$, 18.7, 14.0; MS (EI) $m / z: 392(\mathrm{M}+$ ); HRMS (EI, $m / z)$ calcd for $\mathrm{C}_{22} \mathrm{H}_{24} \mathrm{~N}_{4} \mathrm{O}_{3} \mathrm{~m} / \mathrm{z} 392.1848$, found 392.1843; $[\alpha]_{\mathrm{D}}{ }^{20}-44.0$ (c $0.1, \mathrm{CH}_{2} \mathrm{Cl}_{2}$ ); IR ( $\mathrm{cm}^{-1}$, neat): 1714, 1666.

1-Butyl-2-(2-isopropyl-3-oxo-1,2,3,4-tetrahydro-quinoxalin-6-yl)-1 $H$-benzoimidazole-5-carboxylic Acid Methyl Ester (8k). ${ }^{1} \mathrm{H}$ NMR $\left(300 \mathrm{MHz}, \mathrm{CDCl}_{3}\right) \delta 8.49$ (s, 1H), 8.04 $(\mathrm{dd}, J=8.5,1.5 \mathrm{~Hz}, 1 \mathrm{H}), 7.80(\mathrm{~s}, 1 \mathrm{H}), 7.41(\mathrm{~d}, J=8.5 \mathrm{~Hz}$, $1 \mathrm{H}), 7.26-7.13(\mathrm{~m}, 2 \mathrm{H}), 6.76(\mathrm{~d}, J=8.0 \mathrm{~Hz}, 1 \mathrm{H})$, 4.24-4.29 (m, 3H), 3.97 (s, 3H), $3.92(\mathrm{~m}, 1 \mathrm{H}), 2.27(\mathrm{~m}$, $1 \mathrm{H}), 1.78-1.89(\mathrm{~m}, 2 \mathrm{H}), 1.37-1.25(\mathrm{~m}, 2 \mathrm{H}), 1.09(\mathrm{~d}, J=$ $6.8 \mathrm{~Hz}, 3 \mathrm{H}), 1.02$ (d, $J=6.8 \mathrm{~Hz}, 3 \mathrm{H}), 0.90$ (t, $J=6.0 \mathrm{~Hz}$, $3 \mathrm{H}) ;{ }^{13} \mathrm{C}$ NMR $\left(75 \mathrm{MHz}, \mathrm{CDCl}_{3}\right) \delta 168.0,167.3,155.6$, 143.0, 139.4, 135.5, 125.3, 125.0, 124.5, 122.3, 120.5, 116.5, 113.4, 109.9, 62.1, 52.5, 45.2, 37.0, 32.2, 25.1, 20.4, 19.3, 17.7, 13.9; MS (EI) $m / z: 420$ (M+); HRMS (EI, $m / z)$ calcd for $\mathrm{C}_{24} \mathrm{H}_{28} \mathrm{~N}_{4} \mathrm{O}_{3} m / z$ 420.2161, found 420.2155; $[\alpha]_{\mathrm{D}}{ }^{20}-67.0$ (c 1.1, $\left.\mathrm{CH}_{2} \mathrm{Cl}_{2}\right)$; IR $\left(\mathrm{cm}^{-1}\right.$, neat): 1716, 1633. 
1-Cyclopentyl-2-(2-methyl-3-oxo-1,2,3,4-tetrahydroquinoxalin-6-yl)-1H-benzoimidazole-5-carboxylic Acid Methyl Ester (8I). ${ }^{1} \mathrm{H}$ NMR $\left(300 \mathrm{MHz}, \mathrm{CDCl}_{3}\right) \delta 8.48$ (s, $1 \mathrm{H}), 8.38(\mathrm{~s}, 1 \mathrm{H}), 7.98(\mathrm{dd}, J=8.6,1.5 \mathrm{~Hz}, 1 \mathrm{H}), 7.54$ (d, $J=7.4 \mathrm{~Hz}, 1 \mathrm{H}), 7.17-7.15(\mathrm{~m}, 2 \mathrm{H}), 6.80(\mathrm{~d}, J=8.5 \mathrm{~Hz}$, $1 \mathrm{H}), 4.98(\mathrm{~m}, 1 \mathrm{H}), 4.16-4.12(\mathrm{~m}, 2 \mathrm{H}), 3.97(\mathrm{~s}, 3 \mathrm{H})$, $2.31-2.23(\mathrm{~m}, 2 \mathrm{H}), 2.10-2.06(\mathrm{~m}, 6 \mathrm{H}), 1.53(\mathrm{~d}, J=6.6$ $\mathrm{Hz}, 3 \mathrm{H}) ;{ }^{13} \mathrm{C}$ NMR $\left(75 \mathrm{MHz}, \mathrm{CDCl}_{3}\right) \delta 168.9,167.6,155.8$, 136.3, 135.3, 128.7, 125.8, 124.8, 124.3, 123.6, 121.9, 116.6, 113.6, 111.5, 57.8, 52.0, 51.7, 30.5, 28.9, 25.2, 23.7, 22.9, 18.4; MS (EI) $m / z: 404(\mathrm{M}+$ ); HRMS (EI, $\mathrm{m} / \mathrm{z}$ ) calcd for $\mathrm{C}_{23} \mathrm{H}_{24} \mathrm{~N}_{4} \mathrm{O}_{3} \mathrm{~m} / z$ 404.1848, found 404.1856; $[\alpha]_{\mathrm{D}}{ }^{20}-69.0(c$ 1.0, $\left.\mathrm{CH}_{2} \mathrm{Cl}_{2}\right)$; IR ( $\mathrm{cm}^{-1}$, neat): 1716, 1674.

1-Cyclopentyl-2-(2-isopropyl-3-oxo-1,2,3,4-tetrahydroquinoxalin-6-yl)-1H-benzoimidazole-5-carboxylic Acid Methyl Ester (8m). ${ }^{1} \mathrm{H}$ NMR (300 MHz, $\left.\mathrm{CDCl}_{3}\right) \delta 10.15$ (s, 1H), $8.46(\mathrm{~s}, 1 \mathrm{H}), 7.95(\mathrm{dd}, J=8.5,1.5 \mathrm{~Hz}, 1 \mathrm{H}), 7.48$ $(\mathrm{d}, J=8.5 \mathrm{~Hz}, 1 \mathrm{H}), 7.15-7.08(\mathrm{~m}, 2 \mathrm{H}), 6.70(\mathrm{~d}, J=8.1$ $\mathrm{Hz}, 1 \mathrm{H}), 4.97(\mathrm{~m}, 1 \mathrm{H}), 4.61(\mathrm{~m}, 1 \mathrm{H}), 3.96(\mathrm{~s}, 3 \mathrm{H}), 3.88(\mathrm{~m}$, $1 \mathrm{H}), 2.30-2.23(\mathrm{~m}, 4 \mathrm{H}), 2.08-2.05(\mathrm{~m}, 5 \mathrm{H}), 1.04(\mathrm{~d}, J=$ $7.0 \mathrm{~Hz}, 3 \mathrm{H}), 0.99$ (d, $J=7.0 \mathrm{~Hz}, 3 \mathrm{H}) ;{ }^{13} \mathrm{C}$ NMR $(75 \mathrm{MHz}$, $\left.\mathrm{CDCl}_{3}\right) \delta 168.3,168.1,156.6,143.6,136.9,135.6,126.0$, 125.6, 124.9, 124.1, 122.9, 119.9, 116.8, 113.3, 111.8, 61.8, 58.3, 52.5, 32.0, 30.8, 25.7, 23.0, 20.6, 19.3, 17.6; MS (EI) $\mathrm{m} / \mathrm{z}$ : $432\left(\mathrm{M}+\right.$ ); HRMS (EI, $\mathrm{m} / \mathrm{z}$ ) calcd for $\mathrm{C}_{25} \mathrm{H}_{28} \mathrm{~N}_{4} \mathrm{O}_{3} \mathrm{~m} / \mathrm{z}$ 432.2161, found 432.2163; $[\alpha]_{\mathrm{D}}{ }^{20}-74.0\left(c 1.1, \mathrm{CH}_{2} \mathrm{Cl}_{2}\right)$; IR ( $\mathrm{cm}^{-1}$, neat): 1715, 1667.

Acknowledgment. We gratefully acknowledge National Science Council (NSC) of Taiwan for financial support and also the authorities of the National Chiao Tung University, for providing laboratory facilities.

Supporting Information Available. General experimental procedures and representative ${ }^{1} \mathrm{H}$ NMR, ${ }^{13} \mathrm{C}$ NMR, and chiral HPLC spectra of compounds $\mathbf{8 a}-\mathbf{m}$ as well as some oxidized products 9. This material is available free of charge via the Internet at http://pubs.acs.org.

\section{References and Notes}

(1) (a) Komarov, P. G.; Komarova, E. A.; Kondratov, R. V.; Christov-Tselkov, K.; Coon, J. S.; Chernov, M. V.; Gudkov, A. V. Science 1999, 285, 1733-1737. (b) Stieber, F.; Mazitschek, R.; Soric, N.; Giannis, A.; Waldmann, H. Angew. Chem., Int. Ed. 2002, 41, 4757-4761.

(2) (a) Guillier, F.; Orain, D.; Bradely, M. Chem.Rev. 2000, 100, 2091-2158. (b) Poupart, M. A.; Cameron, D. R.; Chabot, C.; Ghiro, E.; Goudreau, N.; Goulet, S.; Poirier, M.; Tsantrizos, Y. S. J. Org. Chem. 2001, 66, 4743-4751.

(3) Meunier, S.; Siague, J. M.; Sawicki, M.; Calbour, F.; Dezard, S.; Taran, F.; Mioskowski, C. J. Comb. Chem 2003, 5, 201204.

(4) (a) Swamy, K. M. K.; Yeh, W. B.; Lin, M. J.; Sun, C. M. Curr. Med. Chem. 2003, 10, 2403-2424. (b) Ahn, J. M.; Wentworth, P.; Janda, K. D. Chem. Comm. 2003, 48, 0-481.

(5) Miao, W.; Chan, T. K. Org. Lett. 2003, 5, 5003-5005.

(6) (a) Zhang, C. X.; Tong, H. B.; Yan, C. G. J. Comb. Chem 2007, 9, 924-925. (b) Niederhafner, P.; Safarik, M.; Sebestik, J.; Gut, V.; Malon, P.; Hlavacek, J. Tetrahedron Lett. 2006, 47, 1023-1025.

(7) (a) Sun, C. M. Soluble Polymer-Supported Synthesis of Heterocyclic Libraries. In Combinatorial Chemistry Methods and Protocols; Methods in Molecular Biology Series; Bella- vance, L., Ed.; The Humana Press Inc.: New Jersy, 2002; Chapter 10. (b) Sun, C. M. Diversity Oriented Synthesis of Biologically Privileged Scaffolds by Microwave Combinatorial Approach. In Frontiers of Medicinal Chemistry; Reitz A. B. Ed.; Bentham Science Publishers, Ltd.: The Netherlands, 2005; Vol. 2, pp 485-510.

(8) Langer, P.; Doring, M. Eur. J. Org. Chem. 2002, 221-234.

(9) (a) Kappe, C. O. Angew. Chem. Int. Ed. 2004, 43, 62506284. (b) De La Hoz, A.; Diaz-Ortiz, A.; Moreno, A. Chem. Soc. Rev. 2005, 34, 164-178. (c) Gau, Y.; Lam, Y. Org. Lett. 2006, 8, 3283-3285. (d) Dimauro, E. F.; Vitullo, J. R. J. Org. Chem. 2006, 71, 3959-3962.

(10) Horton, D. A.; Bourne, G. T.; Smythe, M. L. Chem. Rev. 2003, 103, 893-930.

(11) (a) Su, Y. S.; Sun, C. M. Synlett 2005, 8, 1243-1246. (b) Lin, M. J.; Sun, C. M. J. Comb. Chem. 2006, 8, 455-458. (c) Wu, C. H.; Sun, C. M. Tetrahedron Lett. 2006, 47, 26012604. (d) Yeh, W. B.; Lin, M. J.; Lee, M. J.; Sun, C. M. Mol. Divers. 2003, 7, 185-198. (e) Lee, M. J.; Sun, C. M. Tetrahedron Lett. 2004, 45, 437-440.

(12) (a) Hirashima, S.; Suzuki, T.; Ishida, T.; Noji, S.; Ando, I.; Komatsu, M.; Ikede, S.; Hashimoto, H. J. Med. Chem. 2006, 49, 4721-4736. (b) Li, Y. F.; Wang, G. F.; He, P. L.; Huang, W. G.; Gao, H. Y.; Tang, W.; Luo, Y.; Feng, C. L.; Shi, L. P.; Ren, Y. D.; Lu, W.; Zuo, J. P. J. Med. Chem. 2006, 49, 47904794.

(13) Jaso, A.; Zarranz, B.; Aldana, I.; Monge, A. J. Med. Chem. 2005, 48, 2019-2025.

(14) Nixey, T.; Tempest, P.; Hulme, C. Tetrahedron Lett. 2002, 43, 1637-1639.

(15) Uwe, J. R.; Henning, W.M. P.; Hauel, N. H.; Handschuh, S.; Mihm, G.; Stassen, J. M.; Wienen, W.; Nar, H. Bioorg. Med. Chem. Lett. 2003, 13, 2297-2302.

(16) Willardsen, J. A.; Dudley, D. A.; Cody, W. L.; Chi, L.; McClanahan, T. B.; Mertz, T. E.; Potoczak, R. E.; Narasimhan, L. S.; Holland, D. R.; Rapundalo, S. T.; Edmunds, J. J. J.Med. Chem. 2004, 47, 4089-4099.

(17) Dudash, J. J.; Zhang, Y.; Moore, J. B.; Look, R.; Liang, Y.; Beavers, M. P.; Conway, B. R.; Rybczynski, P. J.; Demarest, K. T. Bioorg. Med. Chem. Lett. 2005, 15, 4790-4793.

(18) (a) Krchňák, V.; Szabo, L.; Vágner, J. Tetrahedron Lett. 2000, 41, 2835-2838. (b) Morales, G. A.; Corbett, J. W.; DeGrado, W. F. J. Org. Chem. 1998, 63, 1172-1177.

(19) Tung, C. L.; Sun, C. M. Tetrahedron Lett. 2004, 45, 11591162.

(20) Zhang, W.; Tempest, P. Tetrahedron Lett. 2004, 45, 67576760 .

(21) Hilfert, L.; Sarodnick, G.; Kempter, G.; Kleinpeter, E. $\underline{\text { J. Mol. }}$ Struct. 1998, 444, 199-211.

(22) Novellino, E.; Cosimelli, B.; Ehlardo, M.; Greco, G.; Iadanza, M.; Lavecchia, A.; Rimoli, M. G.; Sala, A.; Da Settimo, A.; Primofiore, G.; Da Settimo, F.; Taliani, S.; La Motta, C.; Klotz, K. N.; Tuscano, D.; Trincavelli, M. L.; Martini, C. J. Med.Chem. 2005, 48, 8253-8260.

(23) Alper, L.; Arpaci, O. T.; Aki, E. S.; Yalcin, I. IL. Farmaco. 2003, 58, 497-507.

(24) (a) Molander, G. A.; Felix, L. A. J. Org. Chem. 2005, 70, 3950-3956. (b) Fioravanti, S.; Pellacani, L.; Tardella, P. A.; Morreale, A.; Signore, G. D. J. Comb. Chem. 2006, 8, 808811.

(25) (a) Pan, P. C.; Sun, C. M. Tetrahedron Lett. 1999, 40, 64436446. (b) Yeh, C. M.; Tung, C. L.; Sun, C. M. J. Comb. Chem. 2000, 2, 341-348.

(26) (a) Labelle, M.; Gravel, D. Chem. Commun. 1985, 105-106. (b) Machetti, F.; Bucelli, I.; Indiani, G.; Kappe, C. O.; Guarna, A. J. Comb. Chem. 2007, 9, 454-461. (c) Altamura, M.; Canfarini, F.; Catalioto, R. M.; Guidi, A.; Pasqui, F.; Renzetti, A. R.; Triolo, A.; Maggi, C. A. Bioorg. Med. Chem. Lett. 2002, 12, 2945-2948.

(27) Lee, J.; Murray, W. V.; Rivero, A. J. Org. Chem. 1997, 62, 3874-3879. 
(28) (a) Behrendt, J. M.; Bala, K.; Golding, P.; Hailes, H. C. Tetrahedron Lett. 2005, 46, 643-645. (b) Peng, G.; Sohn, A.; Gallop, M. A. J. Org. Chem. 1999, 64, 8342-8349. (c) Lee, J.; Gauthier, D.; Rivero, R. A. J. Org. Chem. 1999, 64, 3060 3065.

(29) Maeba, I.; Wakimura, M.; Ito, Y.; Ito, C. Heterocvcles 1993, 36, 2591-2695.
(30) The oxidation is mostly prominent in the case when $R_{2}$ is a methyl, isopropyl, or sec-butyl group.

(31) Rangarajan, M.; Kim, J. S.; Sim, S.; Liu, A.; Liu, L. F.; Lavoie, E. J. Bioorg. Med. Chem. 2000, 8, 2591-2600.

(32) Carta, A.; Loriga, M.; Zanetti, S.; Sechi, L. A. IL. Farmaco. 2003, 58, 1251-1255.

CC800137P 